\title{
COMPARATIVE ANALYSIS OF INTERLANGUAGE ERRORS MADE BY JUNIOR HIGH SCHOOL AND SENIOR HIGH SCHOOL
}

\author{
Lilik Nurani \\ STKIP Kumala Lampung, Metro \\ Email: nuraniku86@gmail.com
}

\begin{abstract}
Abstrac: This study deals with the comparative analysis of interlanguage errors made by Junior High School and Senior High School. The objective of this research is to identify the types of interlanguage errors made by the Junior High School and Senior High School. The similarities and the differences of interlanguage error made by Junior High School and Senior High School, and the extend do the native language and the target language influence the student interlanguage system. The similarities of interlanguage errors that found by researcher are: wrong spelling of word, the use of Indonesian word, and omission of bond morpheme's/es' as the plural marker. The researcher found 'the wrong spelling of word, the use of Indonesian word, and omission of bond morpheme "s/es as the plural marker" in Junior High School, in Senior High School composition. The differences of interlanguage error made by Junior High School and Senior High School as follow: the use of $\mathrm{V}$-ing for past event in Junior High school, it is not found in Senior high school composition. There are two influences in students' English namely influenced by first language and influenced by target language; the most dominant influence in students' interlanguage in Junior high school and Senior high school is influenced by the target language. It can be seen from the percentages of it, $85.71 \%$ in Junior High School and $85.71 \%$ in Senior High School composition.
\end{abstract}

Keywords: Interlanguage, Comparative analysis error, Language error

\section{INTRODUCTION}

Learning a second language is a lifelong process and it is a challenging experience for second language learners. English has become an international language and it is used as the language in international relations, and in exchanging knowledge and technology. English occupies the status of a foreign language in
Indonesian education system in both primary and secondary school. It is taught as a compulsory subject in university, junior high school (SMP) and senior high school (SMA), even it has been tried to be taught to the students in some elementary schools. In Indonesia, English is given to the students from the lowest level to the highest level at elementary school until university. Moreover there is a 
lot of play groups has taught English for their students. It means that Indonesian government is going to realize the education national goal, to increase the intelligence of Indonesian people.

All learners make errors in learning a new language. The mother tongue or the first language influences the second language acquisition. The learners of target language always make the errors in the process of second language learning. The errors can be avoiding of the learners although they still beginner or in Junior High School, in the middle or in Senior High School until the student in university. Learner errors are windows into the language learner's mind (Saville Troike $2006: 39$ ).

Interlanguage is a study on the language of the second language learners. According to Selinker $(1977 ; 1997)$ "the learner's language system in neither that of the mother tongue nor native language (NL) nor that of the target language (TL). The learner's language system contains elements of both NL and TL. So, interlanguage is distinct from both their native language and target language. Interlanguage has specific characteristics different from other nature language.

As a language system, interlanguage has specific features different from other natural languages. Adjemian (1976) has proposed three important characteristics of interlanguage: systematicity, permeability, dynamicity, and fossilization. The systematicity means that the interlanguages are natural languages. Permeability means that the susceptibility of interlanguage to infiltration by first language and target language rules or forms. The interlanguage is dynamicity in the sense that the system of rules which learners have in their minds changes frequently, resulting in a succession of interm grammar. And fossilization when the persistence of plateaus of non- target like competence in the interlanguage.

This study deals with interlanguage error. The researcher tries to identify the comparative analysis of interlanguage errors made by Junior High School and Senior High School. The writer uses qualitative, especially in using Error analysis Framework, because the nature of the data is in the form of varied erroneous sentences (quality problem), and qualitative research emphasizes on inductive analysis and places the data as the bases of the discussion to get the answer of the problem. The researcher employs the qualitative research because the data of the research are in the form document or the students' writing.

The writer uses Dulay, Burt, and Krashen (1982:146-197)," in order to present the most useful and commonly used bases for the descriptive classification of errors, they are: linguistic category, surface strategy taxonomy, and comparative taxonomy" to classify types of errors and Dulay, Burt and Krashen (1982: 165-172)"the classification of errors in a comparative taxonomy is based on comparison between the structure of second language errors and certain other types of constructions".

Selinker (1977:1997) said that "the learner's language system in neither 
that of the target mother-tongue nor native language (NL) nor that of the target language (TL). The learner's language system contains elements of both NL and TL". And it also appropriate with Selinker theory that "made reference to linguistic system that are between mother tongue and target language and IL is conceived as the product of interaction between two linguistic systems, the NL and the TL". Adjemian (1976) contributed to the concept of IL by emphasizing its permeability to influence from the L1 and might also be possible to say that the IL is influenced by the L2. Besides that it is appropriate with Selinker concept of interlanguage namely the learner's grammar is permeable. That is, grammar is open to influence from first language and also influence of target language.

The theory of Corder (1982) said that "TL knowledge system being developed by the learner is a dynamic one. It is in a state of flux or constantly changing, as new knowledge of the L2 is added, an adjustment in the competence already acquired take place. The theory by Selinker that the students' interlanguage moves through a series of intermediate stage from the L1 to the L2. It shows that if students' knowledge has added, overtime students' interlanguage move to target language system. And another the theory of (Saville -Troike 2006: 41) said that "interlanguage is dynamic in the sense that 'the system of rules which learners have in their minds changes frequenly, resulting in a succession of interim grammar" (Saville-Troike 2006: 41).
This research has been done by previous researchers, some studies related to analysis of interlanguage errors. Endang Fauziati, in her research "Pola prilaku kesalahan interlanguage (2003)". Her research was conducted to find out the nature and behavior of interlanguage errors. Suhartini's research "The Systematicity of Interlanguage: A Case Study of Senior High School Learning foreign Language (2012)" which only concerns with describing the systematicity of written by second grade of Senior High School of MA MA'ARIF Cepogo Boyolali, describing the frequency of type systematicities, and finding the source influenced systematicity. Fauziati (2003)"she found that the error recovery process resulted in a change interlanguage error conditions. Number of interlanguage errors still exist (persistent), a number of other interlanguage errors still exist with relatively little amount of (non-persistent). While the rest is a mistake that has not appeared again (eradicated), new errors would likely to appear as the students enter a new learning territory, in a sense that they use new linguistic forms. The next previous is Fauziati's research entitled "The Effect of Error Treatment on Interlanguage: a case study of indonesia Learners learning English as a foreign language (2010)", found that ET can change the state of the learners' IL errors; ET contributes to the destabilization process. Errors may persist momentarily but they can be destabilized. The ET still works on the learners who are at their post puberty. Thus, there is a great possibility for the learners to acquire 
complete TL grammar since their ungrammatical items are dynamic. Daryanto's research entitled "Error in Descriptive Text Written by the Ninth Grade Student of SMP Negri 2 Boyolali 2010/2011", in his study shows that the most frequent errors are on omission, there are 99 sentences containing omission $(33.14 \%)$. The next researcher is Summaira Sarfraz, in his research entitled "Error Analysis of the Written English Essays of Pakistani Undergraduate Students: A Case Study", he found that the majority of errors are Grammatical resulting from Interlanguage process. And Asri (2012), in her research entitled "Susceptibility of Interlanguage System: A case Study of students learning English as a Foreign Language in SMP Muhammadiyah 4 Surakarta" and the result of her study is the influence of target language in SMP Muhammadiyah 4 Surakarta greater $(61,75 \%)$ than first language $(38,25 \%)$ in the students' interlanguage system. The researcher conduct a research which aimed at describing the types, similarities, difference, and source of interlanguage error made by the Junior High School, Senior High School, and University students.

The objective of this research is to identify the types of interlanguage errors made by the Junior High School, Senior High School, and University Students, the similarities and the differences of interlanguage error made by Junior High School, Senior High School, and University students, and the extend do the native language and the target language influence the student interlanguage system. The problem states "What are the types of interlanguage errors made by the Junior High School, Senior High School, and University Students?, what are the similarities and the differences of interlanguage error made by Junior High School, Senior High School, and University students, and to what extend do the native language and the target language influence the student interlanguage system?". The study will focus on the attempt to find answer the problems study.

\section{RESEARCH METHOD}

This research is qualitative research; the subjects of the research were 40 students of the Junior High School and 40 students of Senior High School. This study use qualitative method. The research was initiated by assigning the research subjects to write a composition. To get the similar result, the researcher gives instruction to the students to write the written product with the same compositions, the compositions of the written products are: the students' identity, future idea and past experience.

The data are students' errors in writing. The erroneous sentences are taken from 40 pieces of the junior high school students' writing, and 40 pieces of the senior high school students' writing. The sources of data are 120 students' English composition written by students on SMP N 10 METRO, and students on MAN 2 METRO.

The researcher uses elicitation technique as the method of data collection because the data is sought directly from the students. According to Cooke, Nancy J (1994) 
an elicitation technique is any of a number of data collection techniques used in anthropology, cognitive science, counseling, education, knowledge engineering, linguistics, management, philosophy, psychology, or other fields to gather knowledge or information from people. Elicitation, in which knowledge is sought directly from human beings, is usually distinguished from indirect methods such as gathering information from written sources. Elicitation technique is a technique to lure students to produce the writing, and to give instruction to write composition. Technique or procedure that is designed to get a person to actively produce speech of writing, for example asking someone to describe a picture, tell a story, or finish an incomplete sentence.

\section{FINDING AND DISCUSSION}

The Types Of Interlanguage Errors Made By Junior High School And Senior High School

The result of comparative analysis of interlanguage Errors made by Junior High School, and Senior High School indicates that the types of errors made by Junior High School are: (1) tobe, (2) possessive adjective, (3) bound morpheme s/es, (4) verb tense, (5) lexicon, (6) the use of Indonesian word.
Table 1

The Frequency of Errors in Junior High School

\begin{tabular}{|c|c|c|c|c|}
\hline No & Types of Errors & Example & $\begin{array}{l}\text { Freq } \\
\text { uenc } \\
\mathrm{y}\end{array}$ & $\begin{array}{l}\text { Perc } \\
\text { entag } \\
\mathrm{e}\end{array}$ \\
\hline 1 & $\begin{array}{l}\text { To be } \\
\text { a. The use of } \\
\text { singular } \\
\text { copula } \\
\text { "BE" for } \\
\text { plural } \\
\text { subject. } \\
\text { b. Additional } \\
\text { 'Be (am)' } \\
\text { for present } \\
\text { event }\end{array}$ & $\begin{array}{l}\text { - My } \\
\text { hobbies } \\
\text { is } \\
\text { playing } \\
\text { badmint } \\
\text { on and } \\
\text { reading } \\
\text { books } \\
\\
\text { - I am } \\
\text { school } \\
\text { at SMP } \\
10 \\
\text { Metro }\end{array}$ & 14 & $35 \%$ \\
\hline 2 & $\begin{array}{l}\text { Possessive } \\
\text { Adjectives } \\
\text {-The use of } \\
\text { subjective } \\
\text { pronouns for } \\
\text { possessive } \\
\text { adjectives }\end{array}$ & $\begin{array}{l}\text {-I am age } \\
\text { thirteen } \\
\text { years old }\end{array}$ & 5 & $2 \%$ \\
\hline 3 & $\begin{array}{l}\text { Bound } \\
\text { Morpheme's } \\
\text { /es' } \\
\text { - Omission } \\
\text { of Bound } \\
\text { morpheme's/e } \\
\text { s' as the } \\
\text { plural marker }\end{array}$ & $\begin{array}{l}\text { - My } \\
\text { favorite } \\
\text { food are } \\
\text { meatball } \\
\text { and } \\
\text { noodle }\end{array}$ & 12 & $30 \%$ \\
\hline 4 & $\begin{array}{c}\text { Verb Tense } \\
\text { - The use of } \\
\mathrm{V}_{\text {-ing }} \text { for past } \\
\text { event }\end{array}$ & $\begin{array}{l}\text { My } \\
\text { memorab } \\
\text { le } \\
\text { experienc } \\
\text { e } i \text { s } \\
\text { camping } \\
\text { in SMPN } \\
10 \text { Metro. }\end{array}$ & 3 & $7,5 \%$ \\
\hline 5 & $\begin{array}{l}\text { Lexicon } \\
\text {-Wrong } \\
\text { Spelling of } \\
\text { Word }\end{array}$ & $\begin{array}{l}\text { - I'm } \\
\text { threteen } \\
\text { years old }\end{array}$ & 15 & $37,5 \%$ \\
\hline 6 & $\begin{array}{l}\text { The Use of } \\
\text { Indonesian } \\
\text { Word }\end{array}$ & $\begin{array}{l}\text {-I am no } \\
\text { can } \\
\text { melupaka } \\
n \text { her }\end{array}$ & 5 & $\begin{array}{l}12,5 \\
\%\end{array}$ \\
\hline
\end{tabular}


The types of errors in Senior high school : (1) tobe, (2) bound morpheme s/es , (3) preposition, (4) Articles (a, an, the), (5) possessive adjectives, (6) lexicon, (7) the use of Indonesian, (8) objective pronoun, (9) verb tense, (10) false friend, (11) additional apostrophe ('s), (13) the use of singular noun for plural noun.

Table 2

The Frequency of Errors in Senior High School

\begin{tabular}{|c|c|c|c|c|}
\hline No & Types of Errors & Examples & $\begin{array}{c}\text { Frequenc } \\
y\end{array}$ & $\begin{array}{c}\text { Percentag } \\
\mathrm{e}\end{array}$ \\
\hline \multirow[t]{2}{*}{1} & $\begin{array}{l}\text { To be } \\
\text { - The use of } \\
\text { singular } \\
\text { copula 'BE' } \\
\text { for plural } \\
\text { subject }\end{array}$ & $\begin{array}{l}\text { - My } \\
\text { favorite } \\
\text { foods } i s \\
\text { meatball } \\
\text { and noodle }\end{array}$ & 7 & $17,5 \%$ \\
\hline & $\begin{array}{l}\text { - Additional } \\
\text { 'Be (am)' as } \\
\text { form present } \\
\text { event }\end{array}$ & $\begin{array}{l}\text { - I am } \\
\text { School in } \\
\text { Islamic } \\
\text { Senior High } \\
\text { School }\end{array}$ & 7 & $\begin{array}{l}17,5 \\
\%\end{array}$ \\
\hline \multirow[t]{3}{*}{2} & $\begin{array}{l}\text { Bound } \\
\text { Morpheme - } \\
\text { s/-es } \\
\text { a. Omission } \\
\text { of Bound } \\
\text { morpheme } \\
\text { 's/es' as } \\
\text { the plural } \\
\text { marker. }\end{array}$ & $\begin{array}{l}\text { - I have } \\
\text { many story } \\
\text { in here }\end{array}$ & 5 & $12,5 \%$ \\
\hline & $\begin{array}{l}\text { b. Additional } \\
\text { 's' as }\end{array}$ & $\begin{array}{l}\text { - She is a } \\
\text { students }\end{array}$ & 3 & \\
\hline & $\begin{array}{l}\text { Singular } \\
\text { marker. }\end{array}$ & & & $7,5 \%$ \\
\hline \multirow[t]{2}{*}{3} & Preposition & & & \\
\hline & $\begin{array}{l}\text { Omission of } \\
\text { preposition }\end{array}$ & $\begin{array}{l}\text { - I am a } \\
\text { student } \\
\text { Islamic } \\
\text { Senior High } \\
\text { School } 2 \\
\text { Metro }\end{array}$ & 4 & $10 \%$ \\
\hline \multirow[t]{2}{*}{4} & $\begin{array}{l}\text { Articles } \\
\text { (a,an,the) }\end{array}$ & & & \\
\hline & $\begin{array}{l}\text { Omission of } \\
\text { Article } \\
(\mathrm{a}, \mathrm{an}, \mathrm{the})\end{array}$ & $\begin{array}{l}\text { - I hope I } \\
\text { can to } \\
\text { become } \\
\text { doctor. }\end{array}$ & 3 & $7,5 \%$ \\
\hline \multirow[t]{2}{*}{5} & Possessive & & & \\
\hline & $\begin{array}{l}\text { Adjective } \\
\text { - The use of } \\
\text { subjective } \\
\text { pronouns for } \\
\text { possessive } \\
\text { adjectives }\end{array}$ & $\begin{array}{l}\text { - I have a } \\
\text { sister, she } \\
\text { name is } \\
\text { Rizkia } \\
\text { salma dewi }\end{array}$ & 6 & $15 \%$ \\
\hline 6 & $\begin{array}{l}\text { Lexicon } \\
\text { - Wrong } \\
\text { spelling of } \\
\text { word }\end{array}$ & $\begin{array}{l}\text { - My hoby } \\
\text { is wryting }\end{array}$ & 14 & $35 \%$ \\
\hline
\end{tabular}

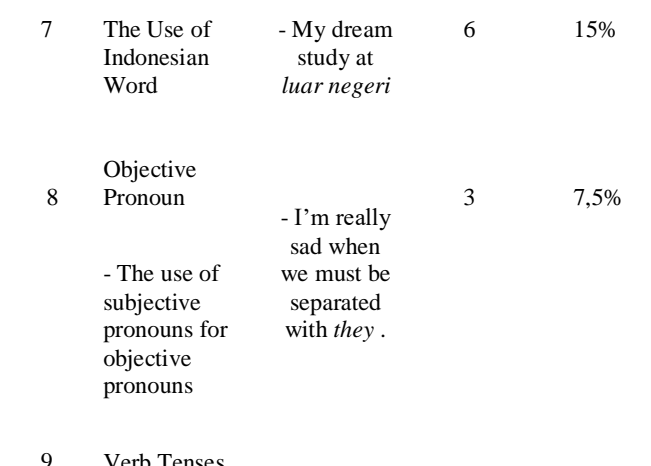

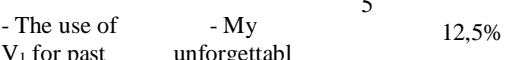

unforgettabl

e

experience
is when I

fall down

from

bicycle

False Friends - I life in 38

10

$$
\begin{array}{ll}
\text { False Friends } & - \text { I life in } 38 \\
& \text { A Banjarejo }
\end{array}
$$

The types of errors in University are: (1) Tobe, (2) bound morpheme's/es, (3) lexicon, (4) the use of Indonesian, (5) verb tense.

\section{The Similarities of interlanguage error made by Junior High School and Senior High School.}

The similarities of interlanguage errors that found by researcher are: wrong spelling of word, the use of Indonesian word, and omission of bond morpheme's/es' as the plural marker. The researcher found 'the wrong spelling of word, the use of Indonesian word, and omission of bond morpheme 's/es as the plural marker" in Junior High School, and in Senior High School composition. 
The differences of interlanguage error made by Junior High School, Senior High School, and University students

The researcher found the differences of interlanguage error made by Junior High School and Senior High School as follow: The use of $\mathrm{V}$-ing for past event in Junior High school, it is not found in Senior high school composition. The errors found in Senior High School, are: false friend, in appropriate apostrophe ('s) is not appropriate, additional's' as singular marker, omission of preposition, the use of singular noun for plural noun, the use of subjective pronouns for objective pronouns, and omission of article (a,an,the), these errors are not found in Junior High School composition.

\section{Tabel 3}

The Comparison of Interlanguage Errors Made by Junior High School, And Senior High School

\begin{tabular}{|c|c|c|c|}
\hline No & Type of Errors & $\begin{array}{c}\text { Junior } \\
\text { High } \\
\text { School }\end{array}$ & $\begin{array}{l}\text { Senior } \\
\text { High } \\
\text { School }\end{array}$ \\
\hline 1 & $\begin{array}{l}\text { The use of } \\
\text { singular copula } \\
\text { 'BE' for plural } \\
\text { subject }\end{array}$ & $\checkmark$ & $\checkmark$ \\
\hline 2 & $\begin{array}{l}\text { The use of } \\
\text { subjective } \\
\text { pronouns for } \\
\text { possessive } \\
\text { adjectives }\end{array}$ & $\checkmark$ & $\checkmark$ \\
\hline 3 & $\begin{array}{l}\text { Additional 'Be } \\
\text { (am)' for present } \\
\text { event }\end{array}$ & $\checkmark$ & $\checkmark$ \\
\hline 4 & $\begin{array}{l}\text { Wrong spelling of } \\
\text { word }\end{array}$ & $\checkmark$ & $\checkmark$ \\
\hline 5 & $\begin{array}{l}\text { The use of } \\
\text { Indonesian word }\end{array}$ & $\checkmark$ & $\checkmark$ \\
\hline 6 & $\begin{array}{l}\text { The use of } \mathrm{V} \text {-ing } \\
\text { for past event }\end{array}$ & $\checkmark$ & - \\
\hline 7 & $\begin{array}{l}\text { The use of } \mathrm{V}_{-1} \text { for } \\
\text { past event }\end{array}$ & - & $\checkmark$ \\
\hline 8 & $\begin{array}{l}\text { Omission of Bond } \\
\text { morpheme 's/es' } \\
\text { as the plural } \\
\text { marker }\end{array}$ & $\checkmark$ & $\checkmark$ \\
\hline 9 & False friend & - & $\checkmark$ \\
\hline 10 & $\begin{array}{l}\text { Additional } \\
\text { apostrophe ('s) is } \\
\text { not appropriate }\end{array}$ & - & $\checkmark$ \\
\hline
\end{tabular}

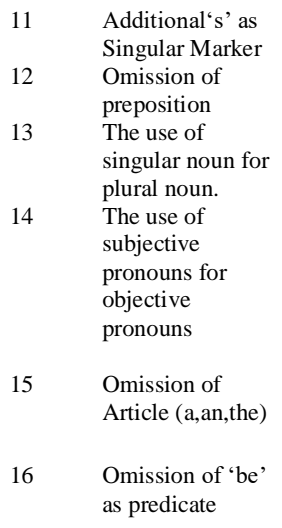

Note:

$$
\begin{array}{ll}
\checkmark & =\text { existence } \\
-\quad & =\text { non existence }
\end{array}
$$

The extend do the native language and the target language influence the student interlanguage system In Junior High School and Senior High School, the students' errors influenced by the target language and the first language (mother tongue). In Junior High School, the students 'errors influenced by the target language $85.71 \%$, and $14.28 \%$ influenced by first language (mother tongue). In Senior High School, the students' errors influenced by the target language $85.71 \%$, and $14.28 \%$ influenced by the first language (mother tongue).

\section{CONCLUSION}

Several conclusions can be drawn from this study. Firstly, that any differences and similarities types of interlanguage errors that found in students' written product of Junior High School and Senior High School. Secondly, the dominant influence of interlanguage errors was influenced by the target language. 
The researcher found some similar type of error in Junior High School and Senior High School, it means that some of errors are permanent and there are any difference types of errors, that found in Junior High School, but do not found in Senior High School and the types of errors found in Senior High School but do not found in Junior High School. It means that there are several types of errors that eradicated and the students' interlanguage move to target language step by step along with development of students' knowledge.

\section{SUGGESTION}

From the conclusion above, the researcher would like to propose suggestion for teachers/lectures, and other future researchers.

\section{For teachers/ lectures}

The teachers/lectures should respect the students' error and give the guidance to the students in teaching and learning process, especially to the students' language acquisition. Teachers/lectures need to develop strategies for overcoming the students' errors.

\section{For other future researchers}

This study is a little part of error analysis in the linguistic research. The study is limited to analyze the students' errors in written product in Junior High School, and Senior High School. The researcher just analyzes the types of errors in students' written product, the similarities and the differences types of errors in Junior High School and Senior High
School, and the extend do the native language and the target language influence the student interlanguage system. For those who are interesting in analyzing the interlanguage errors, it is still open widely to have a research of this type. The field of the study can be the same but there will come up the difference. The difference might be on the data, source, the respondent, and the way of analysis method, underlying theory, the result and improvement.

\section{REFERENCES}

Adjemian, C. 1976. "On the Nature of Interlanguage System." Language Learning. 26: 297320.

Brown, H.D. 2000. Principle of Language Learning and Teaching. New York: Longman.

Corder, S. P.1982. Error Analysis and Interlanguage. Oxford: Oxford University Press.

Fauziati, Endang. 2008 .Teaching of English of foreign language.Surakarta Muhammadiyah University Press.

Fauziati, Endang .2009. Reading on Applied Linguistic.Surakarta: Muhammadiyah University Press.

http://www.edb.gov.hk/en/edusystem/special/resources/serc/irtp/bo ok-3.html\#1 Accessed at December 18 2014, 20:00 Pm. 
Krashen, steven. 1982. Principles and practice in second language Acquisition. Englewood. Cliffs, NJ: Prentice Hall

Moleong. 1985. Metodologi Peneliatian Kualitatif. Bandung PT Remaja Rasa Karya.

Pardiyono, 2006. 12 Writing clues for better writing Competence Yogyakarta : Penerbit Andi Yogyakarta.

Selinker, $\quad$ Larry. 1977. "Interlanguage." In Jack C. Richards (Ed.) Error Analysis: Perspectives on Second Language Acquisition. London: Longman. 